Acta vet. scand. $1964,5,238-256$.

From the Biochemical Institute, The Royal University of Stockholm; and from the Department of Animal Genetics, Nutrition, and Hygiene,

Royal Veterinary College, Stockholm, Sweden.

\title{
ON THE WHOLESOMENESS OF $\gamma$-IRRADIATED POTATOES
}

\author{
By \\ Maire Jaarma and Bengt Henricson
}

The sterilization of foodstuffs, such as potatoes, by irradiation has recently become a subject of interest. As early as 1950, Sparrow \& Christensen (17) found that the germination of potato tubers could be partly or completely inhibited by relatively low $\mathrm{X}$-ray or $\gamma$-radiation doses. Interest in this type of preservation by irradiation is rapidly increasing; see e.g. Errington \& Mac Queen (3), Herrmann (4) and Rubin \& Metlitskii (15). In Sweden, the inhibition of germination in potatoes by $\gamma$-radiation has been under investigation since 1955, Jaarma (6).

The object of the present investigation was to demonstrate, in animal experiments, whether irradiated potatoes, as compared to non-irradiated potatoes, caused any divergent biological effects when used for longer period as food for pigs and rats. Further, the aim was also to examine whether the chemical changes in the potato tubers induced by the $\gamma$-radiation, Herrmann \& Raths (5), Jaarma (7) and Schwimmer et al. (16), could give rise to chemical or enzymatic changes in some. organs or tissues in the animals. Particular emphasis was paid to the investigation of any chemical and enzymatic changes in the animal organism. Due to lack of pig pen space, however, the experiment with pigs had to be considerably limited.

\section{MATERIALS AND METHODS}

The same Swedish variety, Vit Drottning (Eldorado), was used in the experiments performed on both pigs and rats. An investigation 
of the chemical, enzymatic and organoleptic changes in the different varieties of potatoes, Jaarma (8) has indicated that tubers of the Vit Drottning variety, after irradiation with a germination-inhibiting dose (14-15 kilorad at a rate of $175 \mathrm{r} / \mathrm{sec}$.), revert more rapidly to the level of the control tubers than do the other varieties examined. In the experiments with pigs, the potatoes were irradiated with the same above-mentioned dose. The greater quantity of the potatoes, over three tons, was irradiated in $300 \mathrm{~g}$ portions in a Picker Hot-Pot apparatus with a ${ }^{60} \mathrm{Co}$ source. The dose rate in the radiation chamber at the time of the experiment was averagely $175 \mathrm{r} / \mathrm{sec}$. The remaining quantity of potatoes, about one ton, was irradiated with a ${ }^{137} \mathrm{Cs}$ source at the same dose (14-15 kilorad), but at a rate of $625 \mathrm{r} / \mathrm{hr}$.

The above-named potato variety was also used in the experiments with rats, but the radiation dose was about 200 kilorad and the potatoes were given raw. This large radiation dose was applied in order to increase the hypothetical formation of any harmful products which might by formed in the tubers. As these products might be rendered harmless by boiling, the potatoes were given to the rats in a raw state.

In the following, the irradiated potatoes will be denoted I-potatoes, and the non-irradiated control potatoes C-potatoes.

\section{Pigs for breeding}

Two boars and four sows, $3-4$ years old, were given the following daily diet: $4 \mathrm{~kg}$ potatoes and $2 \mathrm{~kg}$ food concentrate, the latter consisting of $68.5 \%$ oats and barley $1: 1,20 \%$ wheat bran, $4 \%$ fish meal, $1 \%$ fodder yeast, $1.5 \%$ chalk, $0.5 \%$ sodium chloride, and $0.5 \%$ vita$\operatorname{mins}(\mathrm{A}+\mathrm{D})$.

One boar and three sows were given irradiated potatoes, and one boar and one sow received control potatoes. All the animals were kept on this ration for about four months and subsequently slaughtered. At the time of farrowing, the potatoes were omitted for one week.

Post-mortem examination of the pigs was made in connection with the slaughter. Histological examination was made on samples from the stomach, small intestine, liver, heart, and the kidneys. Fat and protein determinations were made on samples of liver. Quality determinations were made on the back fat (the greater part of the carbohydrates in the diet, which are not used in the metabolism, is transformed into fats and is found in the subcutaneous fat layer), which was removed immediately after slaughter. After grinding, the fat was extracted by melting in boiling water for one hour, pressed and filtered, Dahl (2). The "keepability" of the fat was determined by measuring the peroxide content ( $\mathrm{mg}$ active oxygen/ $\mathrm{kg}$ fat after storing in the absence of light at $55^{\circ}$ ) according to Lea's simplified method (11); cf. Dahl (2). The iodine value was determined according to Hanus, and the content of free fatty acids was determined by dissolving the fat in equal volumes of ethyl ether and ethanol, and titrating with potassium hydroxide. 


\section{Fattening pigs}

Ten pigs were divided into two groups: one group which was given irradiated potatoes, denoted as I-group $\left(3 \sigma^{x}, 2\right.$ $)$, and one group which was given non-irradiated control potatoes, called C-group $\left(2 \sigma^{x}, 3\right.$ o $)$. The pigs were fed for a full period of fattening, $i$. e. from about $25 \mathrm{~kg}$ unto about $90 \mathrm{~kg}$ live weight. The composition of the ration is given in Table $I$, week 1 indicating the first week of the

T a b l e I. Fodder ration given to fattening pigs.

\begin{tabular}{ccc}
\hline \multirow{2}{*}{ Week } & \multicolumn{2}{c}{ Kg per pig and day } \\
\cline { 2 - 3 } & Potatoes & Food concentrate $\left.{ }^{*}\right)$ \\
\hline 1 & 1 & 1 \\
$2-4$ & 1.5 & 1.5 \\
$5-6$ & 2 & 1.5 \\
7 & 2.5 & 2 \\
8 & 3 & 2 \\
9 & 3 & 2 \\
$10-11$ & 4 & 2 \\
$12-15$ & 4 & 2.5 \\
\hline
\end{tabular}

*) For explanation, see p. 239.

fattening period. Observations were made daily of the general conditions of the pigs (appetite, vitality, etc.). At intervals of three weeks, $i$. e. five times during the course of the experiment, a sample of blood was taken from the vena jugularis for the following tests: content of haemoglobin, total amount of white blood cells and differential counts, residual nitrogen, and the activity of glutamic-oxaloacetic transaminase (GOT), and ornithinecarbamyl transferase (OCT). In addition, the activity of GOT, OCT, and glutamic-pyruvic transaminase (GPT) was determined in liver samples at slaughter. The tissues were homogenized in $0.1 \mathrm{M}$ phosphate buffer $(\mathrm{pH} 7.4)$ and the enzyme activities were determined according to Reichard (13a) and Reitman \& Frankel (14). In one animal from each group, determinations were made of the incorporation of iron $\left({ }^{59} \mathrm{Fe}\right)$ into the circulating erythrocytes $(13)$, of the blood volume using ${ }^{51} \mathrm{Cr}$ (18), and of continuous haematocrit values. Similar samples to those taken from breeding pigs were taken when the animals were slaughtered (see above).

\section{Laboratory rats}

In this investigation, albino rats (Wistar) from the laboratory stock were used (progeny of stock bred for 25 years at the Department of Animal Genetics, Nutrition, and Hygiene, The Royal Veterinary College). The I-group and the $\mathrm{C}$-group each contained 28 rats, equally divided as to sex. When the rats reached a weight of $35 \mathrm{~g}$, they were 
fed with potatoes, and the first feeding period was continued for $\mathbf{9 0}$ days. The food, which was given ad libitum, consisted of $53 \%$ raw potatoes, $16 \%$ casein, $12 \%$ fish meal, $2.8 \%$ ground maize, $5.9 \%$ crushed wheat, $1.2 \%$ crushed oats, $2.0 \%$ ground bread crumbs, $0.1 \%$ calcium carbonate, $1 \%$ sodium chloride, $1.5 \%$ fodder yeast, $2.5 \%$ fish liver oil, and $2 \%$ hay and straw dust (the latter being introduced about two months after the experiment commenced; see explanation below).

It was observed that the relatively large proportion of raw potatoes in the diet caused abnormal colonic and vermiform digestion, resulting in the formation of gas and diarrhoea. A few deaths were also caused by ileus. Digestion returned to normal when about $2 \%$ hay and straw dust was added to the diet. In connection with littering, however, the potatoes had to be supplemented by a more protein-rich foodstuff.

The animals were weighed once a week. After 90 days, the rats were divided into the following groups: four female and four male rats from both the I-group and the C-group were taken for breeding and control of fertility; seven male rats were castrated and killed. Half a testicle from each of these latter animals was removed and immediately fixed in acetic acid-ethanol $1: 4$, embedded in paraffin, and cut in sections of $5 \mu$ thickness. The sections were stained with Gomori's haematoxylin. A-spermatogonia, resting cells, and pachytene nuclei from the spermatocytogenic stage VII, Leblond \& Clermont (12) were counted in ten circular tubular sections from each rat. Ten male rats and two female rats from each group were killed and a full autopsy made.

\section{RESULTS}

\section{Pigs for breeding}

No deleterious effects on the general health of the animals due to the I-potato diet could be observed. The boar which was fed on I-potatoes provided evidence of its fertility. The control boar was not used for mating for various reasons. Three of the sows farrowed during the investigation with the following results : sow No. 122 (I-potatoes) 11 offspring (7 $\sigma^{x}, 4$ \%), three dead at birth; sow No. 974 (I-potatoes) 9 offspring ( $\left.3 \sigma^{x}, 6 q\right)$, none dead at birth; sow No. 1316 (C-potatoes) 15 offspring (8 $\sigma^{x}, 7$ o), two dead at birth. One of the sows, fed on I-potatoes, had difficulty conceiving as early as three or four months before the investigation began and did not become pregnant during the course of the experiment.

Post-mortem examination after slaughter showed that there were no differences between the I-group and the C-group. The histological examination, however, disclosed that a sub-acute 
enteritis of the small intestine was present in all cases. In some of the animals, haemosiderosis was found in the Kupffer cells of the liver, and isolated enlarged cell nuclei in the heart muscle. These changes could be found to the same extent in both the I-group and the C-group.

The results of the fat and liver determinations are shown in Table II.

T a b le I I. Biochemical investigations of back fat and liver tissue from breeding pigs. I-group fed on irradiated, C-group on non-irradiated control potatoes.

\begin{tabular}{|c|c|c|c|c|c|c|c|c|}
\hline \multirow[b]{2}{*}{ I-group } & \multirow[b]{2}{*}{ C-group } & \multirow{2}{*}{$\begin{array}{c}\text { Total amount } \\
\text { potatoes given } \\
\text { to the animal } \\
\text { kg }\end{array}$} & \multicolumn{3}{|c|}{ Back fat } & \multicolumn{3}{|c|}{ Liver } \\
\hline & & & $\begin{array}{l}\text { Iodine } \\
\text { value }\end{array}$ & $\begin{array}{c}\text { Free } \\
\text { fatty } \\
\text { acids } \\
\%\end{array}$ & $\begin{array}{l}\text { Keep- } \\
\text { ability } \\
\text { days }\end{array}$ & $\begin{array}{c}\text { Dry } \\
\text { weight } \\
0 \%\end{array}$ & $\begin{array}{c}\text { Protein } \\
\text { wet } \\
\text { weight } \\
0 \% \\
\end{array}$ & $\begin{array}{c}\text { Fats } \\
0 \% \text { of } \\
\text { dry } \\
\text { weight }\end{array}$ \\
\hline \multirow[t]{2}{*}{$3800^{x}$} & \multirow{5}{*}{ Jacob $\sigma^{x}$} & 560 & 67.9 & 0.03 & 13.2 & 27.8 & 25.6 & 9.9 \\
\hline & & 560 & 68.0 & 0.04 & 8.1 & 25.8 & 33.5 & 9.9 \\
\hline 122 우 & & 420 & 70.4 & 0.08 & 8.5 & 21.8 & 17.7 & 17.5 \\
\hline 974 우 & & $420^{\circ}$ & 68.0 & 0.09 & 4.5 & 30.0 & 21.4 & 11.2 \\
\hline \multirow[t]{2}{*}{$1095 \stackrel{+}{\circ}$} & & 192 & 67.9 & 0.29 & 5.9 & & & \\
\hline & 1316 우 & 576 & 67.9 & 0.08 & 9.0 & 28.5 & 18.0 & 8.3 \\
\hline \multirow[t]{2}{*}{$\left.940 \subsetneq^{\star}\right)$} & & 450 & & & & & & \\
\hline & $\left.1315 q^{\star}\right)$ & 140 & & & & & & \\
\hline
\end{tabular}

*) Separately slaughtered.

\section{Fattening pigs}

The general conditions of the pigs remained unaltered throughout the investigation. The growth rate is shown in Figure

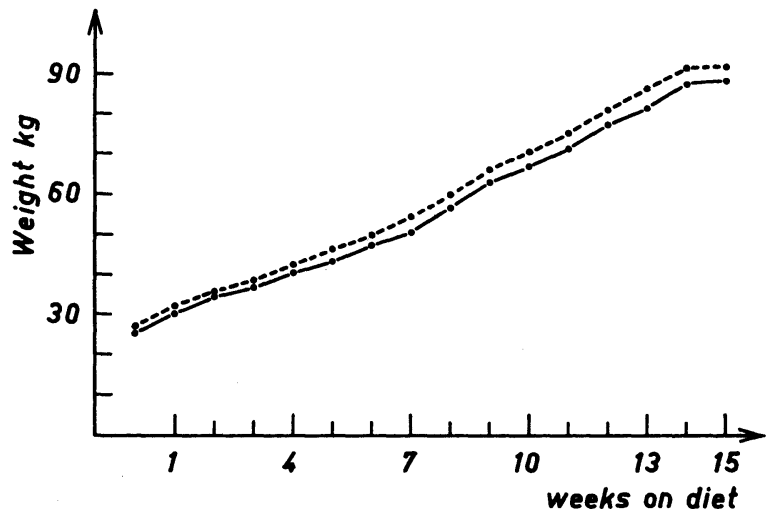

F i g. 1. Body weight of fattening pigs per week. Dashed line: I-group; solid line: C-group. 

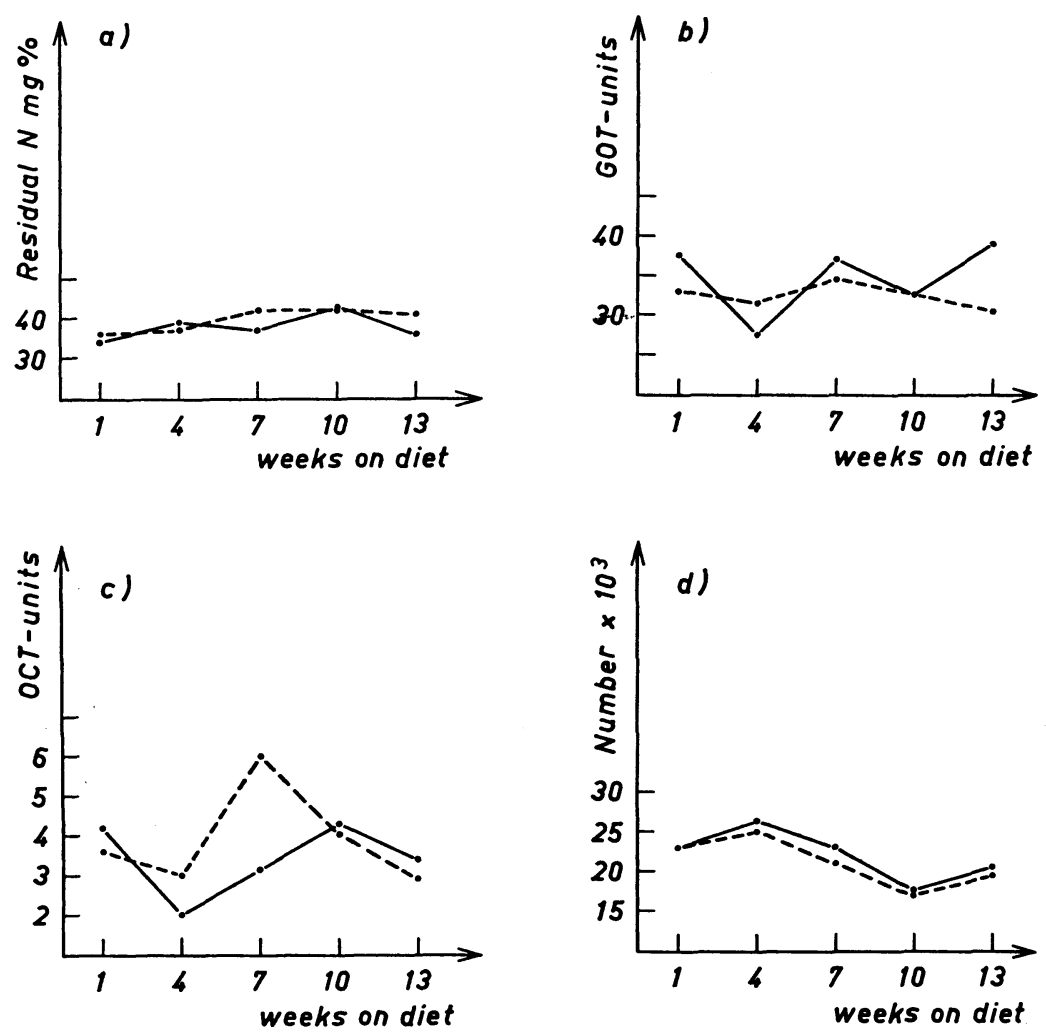

Fig. 2. Blood examination on fattening pigs. a: Residual nitrogen; b: glutamic-oxaloacetic transaminase (GOT); c: ornithine-carbamyl transferase (OCT); d: total number of white blood cells. Dashed line: I-group; solid line: C-group.

1, where the average weight per week is given for both I- and C-groups.

Figures 2 a-d present the results of the blood tests. Differential white blood cell counts did not indicate any systematic differences between the I- and C-groups. The values for residual nitrogen and the transaminases examined were also equal in both groups. Haemoglobin values for blood from some of the animals in the I-group were, however, much higher than the corresponding values for some of the animals in the C-group; see Figure 3.

In order to study in more detail the cause of this higher haemoglobin values, determination of the blood volume and iron incorporation was made on one animal from each group, as 

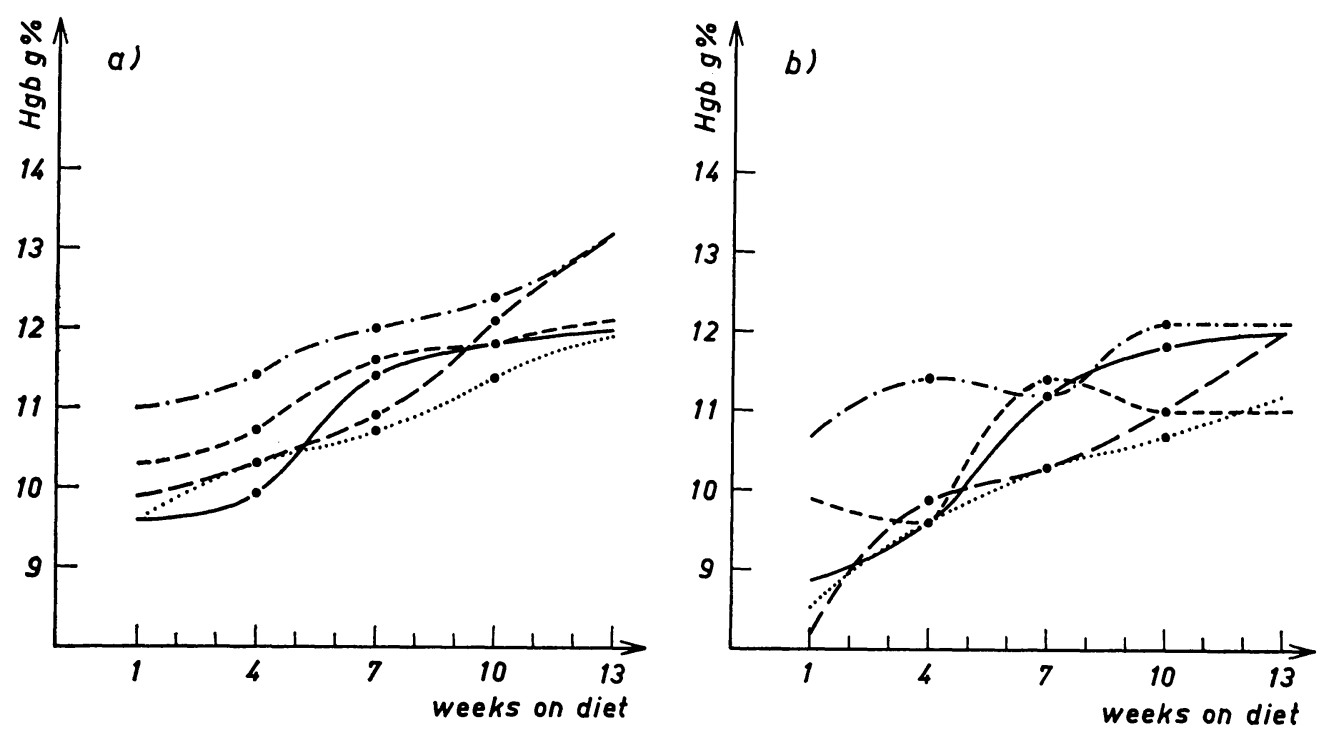

Fig. 3. Individual haemoglobin values for the fattening pigs. a: I-group. b: C-group.

T a b l e I I I a. Iron incorporation and blood volume in pigs for fattening. I-group fed on irradiated, C-group on non-irradiated control potatoes.

\begin{tabular}{cccccccc}
\hline Group & $\begin{array}{c}\text { Haemo- } \\
\text { globin } \\
\mathrm{g} \%\end{array}$ & $\begin{array}{c}\text { Haema- } \\
\text { tocrit } \\
\text { \% }\end{array}$ & $\begin{array}{c}\text { Blood } \\
\text { volume }\end{array}$ & $\begin{array}{c}\text { Red blood } \\
\text { corpuscles } \\
\text { volume }\end{array}$ & $\begin{array}{c}\text { Plasma } \\
\text { volume }\end{array}$ & $\begin{array}{c}59 \text { Fe incorp- } \\
\text { oration }\end{array}$ & $\begin{array}{c}\text { Total } \\
\text { haemo- } \\
\text { globin } \mathrm{g}\end{array}$ \\
\hline $\mathrm{I}$ & 15.1 & 46 & 52.0 & 21.3 & 30.6 & 70.1 & 785 \\
$\mathrm{C}$ & 12.1 & 36 & 53.8 & 17.2 & 36.6 & 76.8 & 651 \\
\hline
\end{tabular}

T a b l e I I I b. Iron concentration in the liver of pigs for fattening. I-group fed on irradiated, C-group on non-irradiated control potatoes.

\begin{tabular}{ccc}
\hline Group & $\mu \mathrm{g} \mathrm{Fe} / \mathrm{g}$ fresh liver & $\mu \mathrm{g} \mathrm{Fe} / \mathrm{g}$ dry liver \\
\hline I & 385 & 1360 \\
$\mathrm{C}$ & 418 & 1530 \\
\hline
\end{tabular}

mentioned previously. The results are given in Tables III $\mathbf{a}$ and $\mathbf{b}$, and the results of the transaminase and transferase determinations in liver are presented in Table IV.

No indication of any pathological change was found by macroscopic investigation made after slaughter. On histological exami- 
T a b l e I V. Liver transaminases and transferase in pigs for fattening. I-group fed on irradiated, C-group on non-irradiated control potatoes.

GOT = glutamic-oxaloacetic transaminase; GPT $=$ glutamic-pyruvic transaminase; OCT = ornithinecarbamyl transferase.

\begin{tabular}{|c|c|c|c|c|c|c|c|}
\hline \multirow[t]{2}{*}{ Group } & \multirow[t]{2}{*}{$\begin{array}{l}\text { Numbcr } \\
\text { of pigs }\end{array}$} & \multicolumn{2}{|c|}{$\begin{array}{l}\text { GOT-units } \times 10^{4} \\
\text { (dilution } 1: 16)\end{array}$} & \multicolumn{2}{|c|}{$\begin{array}{l}\text { GPT-units } \times 10^{4} \\
\text { (dilution } 1: 50 \text { ) }\end{array}$} & \multicolumn{2}{|c|}{$\begin{array}{l}\text { OCT-units } \times 10^{4} \\
\text { (dilution } 1: 50)\end{array}$} \\
\hline & & Mean & Range & Mean & Range & Mean & Range \\
\hline I & 5 & 283 & $240-347$ & 109 & $43-161$ & 2616 & $1201-3871$ \\
\hline C & 5 & 257 & $179-390$ & 97 & $31-165$ & 1506 & $723-2663$ \\
\hline
\end{tabular}

nation, no differences between the groups were noted and the same observations as those in the case of breeding pigs were made. Table $\mathrm{V}$ gives the results of the liver analyses and Table VI presents the results of the fat tests.

\section{Laboratory rats}

The growth rate during the investigation is shown in Figure 4. A tendency towards a more rapid growth rate was exhibited especially by the female rats fed on I-potatoes.

It was obvious that the large proportion of raw potatoes in the diet was not physiologically quite suitable for the rats, and caused digestion disturbances in which some of the animals died, three in the I-group and one in the C-group. Swelling in the abdominal region following the abnormal colonic digestion, was

T a b l e V. Content of protein, fat, and dry substance in the liver of fattening pigs. I-group fed on irradiated, C-group on non-irradiated control potatoes.

\begin{tabular}{|c|c|c|c|c|c|}
\hline \multirow{2}{*}{ Group } & \multirow{2}{*}{$\begin{array}{l}\text { Animal } \\
\text { number } \\
\text { and sex }\end{array}$} & \multicolumn{2}{|c|}{ Liver weight. } & \multirow{2}{*}{$\begin{array}{c}\text { Proteins } \\
0 \% \text { of wet } \\
\text { weight } \\
\text { liver }\end{array}$} & \multirow{2}{*}{$\begin{array}{l}\text { Fats } \\
\% \text { of dry } \\
\text { weigt } \\
\text { liver }\end{array}$} \\
\hline & & $\begin{array}{c}\text { wet } \\
\text { g }\end{array}$ & $\begin{array}{l}\text { dry } \\
0 \%\end{array}$ & & \\
\hline I & $10^{x}$ & 1160 & 28.0 & 20.9 & 10.3 \\
\hline,,-- & 2 \% & 1350 & 27.2 & 21.8 & 9.6 \\
\hline,,-- & 3 우 & 1340 & 28.5 & 21.5 & 12.6 \\
\hline,-- & $40^{x}$ & 1650 & 27.2 & 20.9 & 9.8 \\
\hline,,-- & $5 \sigma^{x}$ & 1850 & 29.0 & 21.3 & 9.6 \\
\hline C & 6 우 & 1280 & 28.2 & 19.6 & 19.5 \\
\hline,,-- & $7 \stackrel{+}{q}$ & 1300 & 27.6 & 18.9 & 15.9 \\
\hline,- & $8 \frac{7}{\sigma^{x}}$ & 1730 & 27.1 & 23.7 & 12.2 \\
\hline,- & 9 우 & 1540 & 28.6 & 20.5 & 13.1 \\
\hline,,-- & $100^{x}$ & 1770 & 27.2 & 23.1 & 12.4 \\
\hline
\end{tabular}




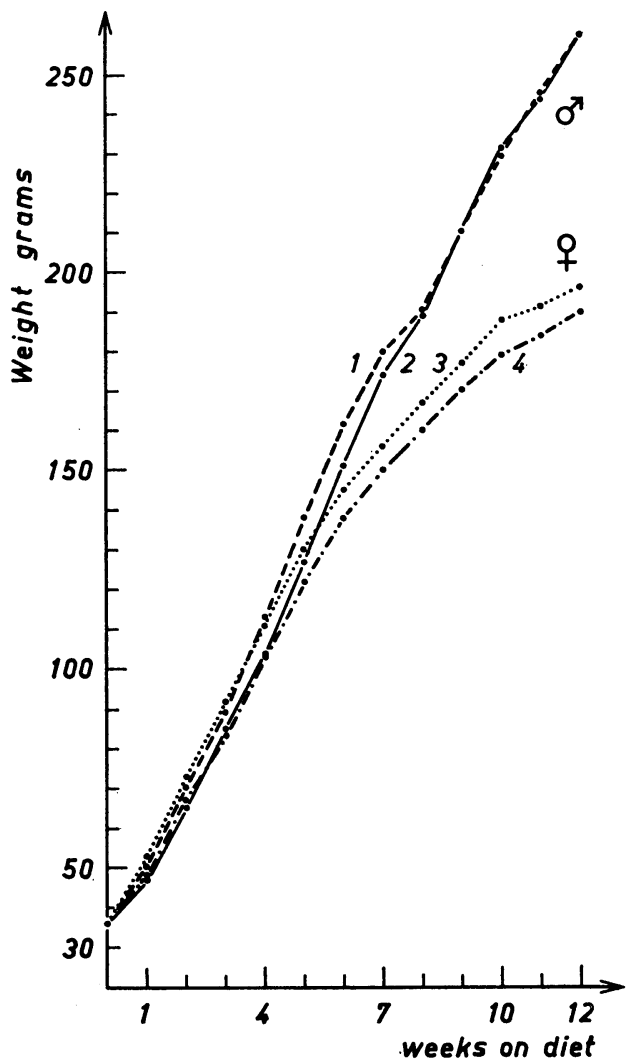

F ig. 4. Body weight of rats per week. 1 and 3: I-group; 2 and 4:

C-group.

T a b l e VI. Results of analyses of back fat from fattening pigs.

I-group fed on irradiated, C-group on non-irradiated control potatoes.

\begin{tabular}{|c|c|c|c|c|c|c|c|c|c|}
\hline \multirow{2}{*}{ Group } & \multirow{2}{*}{$\begin{array}{c}\text { Animal } \\
\text { number } \\
\text { and sex }\end{array}$} & \multirow{2}{*}{$\begin{array}{l}\text { Weight } \\
\text { of animal } \\
\text { at start } \\
\text { kg }\end{array}$} & \multirow{2}{*}{$\begin{array}{c}\text { Live } \\
\text { weight } \\
\text { kg }\end{array}$} & \multirow{2}{*}{$\begin{array}{c}\text { Iodine } \\
\text { value }\end{array}$} & \multirow{2}{*}{$\begin{array}{c}\text { Free } \\
\text { fatty } \\
\text { acids } \\
\%\end{array}$} & \multirow{2}{*}{$\begin{array}{l}\text { Keep- } \\
\text { ability } \\
\text { days }\end{array}$} & \multicolumn{3}{|c|}{ Mean values } \\
\hline & & & & & & & $\begin{array}{l}\text { lodine } \\
\text { value }\end{array}$ & $\begin{array}{l}\text { Free fatty } \\
\text { acids } \\
\%\end{array}$ & $\begin{array}{l}\text { Keep- } \\
\text { ability } \\
\text { days }\end{array}$ \\
\hline I & $10^{x}$ & 27.0 & 74.0 & 57.5 & 0.15 & 7.9 & & & \\
\hline,,-- & 2 우 & 32.5 & 84.5 & 55.0 & 0.11 & 7.9 & & & \\
\hline,,-- & 3 \% & 35.0 & 85.5 & 58.2 & 0.18 & 5.8 & 58.3 & 0.14 & 6.1 \\
\hline,-- & $40^{x}$ & 29.5 & 98.0 & 62.4 & 0.14 & 4.0 & & & \\
\hline,-- & $5 \sigma^{x}$ & 34.0 & 115.0 & 58.3 & 0.14 & 5.0 & & & \\
\hline $\mathbf{C}$ & 6 우 & 33.0 & 79.0 & 56.8 & 0.20 & 9.1 & & & \\
\hline,,-- & $7 \stackrel{+}{q}$ & 30.0 & 84.0 & 60.6 & 0.20 & 5.2 & & & \\
\hline,-- & $80^{x}$ & 27.5 & 96.0 & 59.7 & 0.16 & 5.0 & 60.8 & 0.17 & 6.0 \\
\hline,,-- & 9 우 & 28.0 & 84.0 & 67.6 & 0.17 & 3.4 & & & \\
\hline,-- & $100^{+}$ & 30.0 & 94.5 & 59.3 & 0.14 & 7.1 & & & \\
\hline
\end{tabular}


observed in practically all the rats. The large proportion of potatoes in the diet had been chosen deliberately so that the rats would consume as large a quantity of I-potatoes as possible. In spite of the low amount of protein, growth was satisfactory, and after the addition of vegetable fibres, the unfavourable effect on the digestive tract disappeared almost completely.

T a b l e V I I. Results of first mating period for rats fed on irradiated (I) and non-irradiated control (C) potatoes, respectively; $\mathrm{N}=$ conventional food (for explanation, see below).

\begin{tabular}{cc}
$\begin{array}{c}\text { Number and group } \\
\text { of parents }\end{array}$ & $\begin{array}{c}\text { Offspring } \\
\text { Mean number per } \%\end{array}$ \\
$4 \mathrm{I} \sigma^{x} \times 10 \mathrm{I} \%$ & 9.1 \\
$4 \mathrm{C} \sigma^{x} \times 10 \mathrm{C}$ o & 8.0 \\
$4 \mathrm{I} \sigma^{x} \times 4 \mathrm{~N} q$ & 6.8 \\
$4 \mathrm{C} \sigma^{x} \times 4 \mathrm{~N} q$ & 7.3 \\
$2 \mathrm{~N} \sigma^{x} \times 2 \mathrm{~N} q$ & 9.0 \\
\hline
\end{tabular}

T a b l e V I I I. Results of second mating period for rats fed on irradiated (I) and non-irradiated control (C) potatoes, respectively; $\mathbf{N}=$ conventional food (for explanation, see below). The female rats are the same as in the first period.

\begin{tabular}{cc}
\hline $\begin{array}{c}\text { Number and group } \\
\text { of parents }\end{array}$ & $\begin{array}{c}\text { Offspring } \\
\text { Mean }\end{array}$ \\
\hline $3 \mathrm{~N} \sigma^{x} \times 10 \mathrm{I} \%$ & 10.1 \\
$3 \mathrm{~N} \sigma^{x} \times 9 \mathrm{C} \%$ & 10.1 \\
$5 \mathrm{~N} \sigma^{x} \times 9 \mathrm{~N} \%$ & 8.9 \\
\hline
\end{tabular}

*) Cf. Table VII.

The number of offspring produced in both groups, as a measure of fertility, is shown in Tables VII and VIII. Two litters were produced. Potatoes were given to the females until littering, but during the lactation period (about three weeks) a more protein-rich diet was given. During the next mating period and during the pregnancy (about eight weeks) the rats were given the potato diet the whole time. Those rats, denoted by $\mathrm{N}$ in Tables VII and VIII, were fed on the normal laboratory diet $(23.3 \%$ ground maize, $50 \%$ crushed wheat, $10 \%$ crushed oats, $16 \%$ ground bread crumbs, $0.5 \%$ calcium carbonate, $0.2 \%$ sodium chloride, vitamins $(A+D)$, and fodder yeast) and were included for comparison. 
T a b l e I X. Mean number of cells in stage VII of the spermatogenetic cycle in male rats. I-group fed on irradiated, C-group on non-irradiated control potatoes.

\begin{tabular}{cccccc}
\hline Group & $\begin{array}{c}\text { Number } \\
\text { of } \\
\text { animals }\end{array}$ & $\begin{array}{c}\text { Number of } \\
\text { tubuli } \\
\text { counted } \\
\text { per animal }\end{array}$ & $\begin{array}{c}\text { Mean number of cells per tubulus } \\
\text { Spermatogonia } \\
\text { type A }\end{array}$ & $\begin{array}{c}\text { Resting } \\
\text { cells }\end{array}$ & $\begin{array}{c}\text { Pachytene } \\
\text { nuclei }\end{array}$ \\
\hline & & & & & \\
I & 7 & 10 & $1.1 \pm 0.1$ & $65.1 \pm 2.9$ & $86.6 \pm 2.8$ \\
C & 7 & 10 & $1.1 \pm 0.1$ & $63.6 \pm 2.5$ & $82.2 \pm 2.1$ \\
\hline
\end{tabular}

By detailed histological examination of the testicles from several of the male rats, a careful control of activity of the germinal epithelium could be made. Table IX shows the average number of cells of different types found in 10 circular tubuli sections per rat. It should be observed that the numerical difference between resting cells and pachytenes, which constitute two successive generations of primary spermatocytes, can be explained by the different sizes of the nuclei. The former type of nucleus has a diameter of about $6 \mu$, the latter $10 \mu$. A cell count in a tubular section (in this case $5 \mu$ thick) will reveal a relatively larger number of nuclei where the diameter of the respective nucleus type is larger. In this connection, however, the interesting comparison is that between the nuclei in the I-group and the $\mathrm{C}$-group and a correction for making the nucleus types comparable is therefore not necessary. It should be pointed out that the total area of the tubuli, chosen at random, were satisfactorily equal in the two groups as the mean value of the tubulus diameter was $260.7 \mu$ for the I-group and $252.5 \mu$ for the C-group. Thus, no correction for this factor is required.

\section{DISCUSSION AND CONCLUSIONS}

The investigation described here is not to be regarded as conclusive, particularly in the case of the pigs. Owing to biological variations, larger groups than those available are necessary for definite conclusions.

Clinically, no unfavourable observations could be made concerning the health of the I-group or the C-group. However, the potato diet per se, apart from irradiation, has not left the digestive tract unaffected, particularly with regard to the rats. As the changes were the same in both groups, the histological obser- 
vations can be explained by the relatively large proportion of carbohydrates in the diet. Boiled potatoes were given to the pigs in quantities, which did not exceed the conventional amount recommended. Thus the symptoms observed of an inflammation of duodenum are astonishing. The more drastic effect of the raw potato diet on the digestive tract of the rats is more easily explained. This effect was apparent in both the I-group and C-group and was considerably alleviated by the addition of vegetable fibres. The growth, however, of the pigs was satisfactory, and the growth rate quite comparable to that of pigs raised commercially. Figure 1 shows that I-potatoes had the same effects as C-potatoes; the numerical difference is not statistically significant. The same conclusion can be drawn regarding the growth of the rats; here there is, however, an obvious indication of the superiority of the I-potatoes.

If the irradiated potatoes actually have properties which stimulate growth, this might possibly be due to more easily digested carbohydrates, which are produced in the potatoes by irradiation. The chemical analysis of carbohydrates in irradiated potatoes provides certain evidence that this may be the case; $\mathrm{cf}$. Schwimmer et al. (16), and Jaarma (7). From a current investigation on rats - where chemical analysis and enzymatic determinations have been performed on the potatoes used, both before and after irradiation - it is evident that the increase in the growth rate might depend on changes in protein structure, free amino acids, and transaminations, Jaarma (9).

The pork quality was fully satisfactory. The average "keepability" of back fat from pigs in the I-group was the same as for the C-group, but one of the animals, No. 9 of the C-group, gave very divergent results. In the case of this animal, the back fat had a low "keepability", and the iodine value was extremely high; see Table VI. The content of free fatty acids (mean value) in the I-group was slightly lower than that for the C-group, and the same applied to the iodine value, but, as seen in Table VI, the individual variations were so large that these group differences are not statistically significant. Tests were performed in order to determine the rate of occurrence of rancidity in the unmelted back fat, and the results will be published elsewhere, Jaarma (9).

The blood investigations performed on fattening pigs gave divergent results in one detail in the two groups. The haemoglobin values increased more in the I-group than in the C-group. 


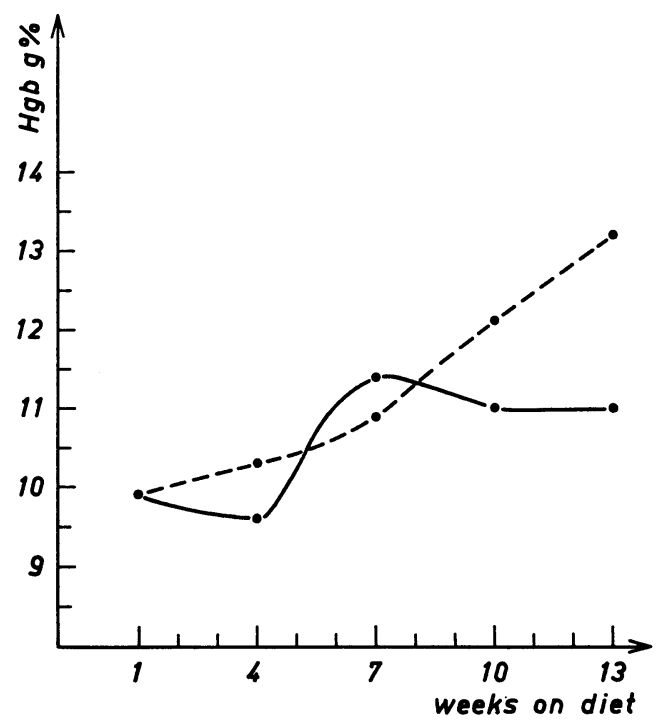

F i g. 5 a. Haemoglobin values for two fattening pigs with the same initial values. Dashed line: fed on I-potatoes; solid line: fed on C-potatoes.

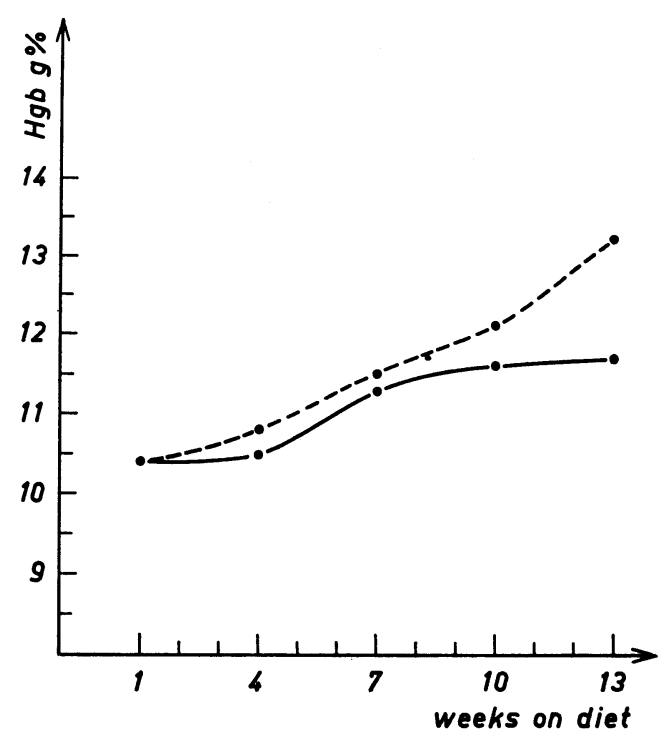

F i g. 5 b. Mean values of haemoglobin for all the fattening pigs with the same initial values. Dashed line: I-group; solid line: C-group. 
This phenomenon was particularly noticeable in some of the test animals, whereas the difference in the remaining animals was moderate. It can be seen from Figure 3 that the individual variations of haemoglobin content in the blood of the fattening pigs was high at the beginning of the investigation. (Division of the animals into I- and C-groups was based on sex and weight). A statistical determination of the haemoglobin values, based on

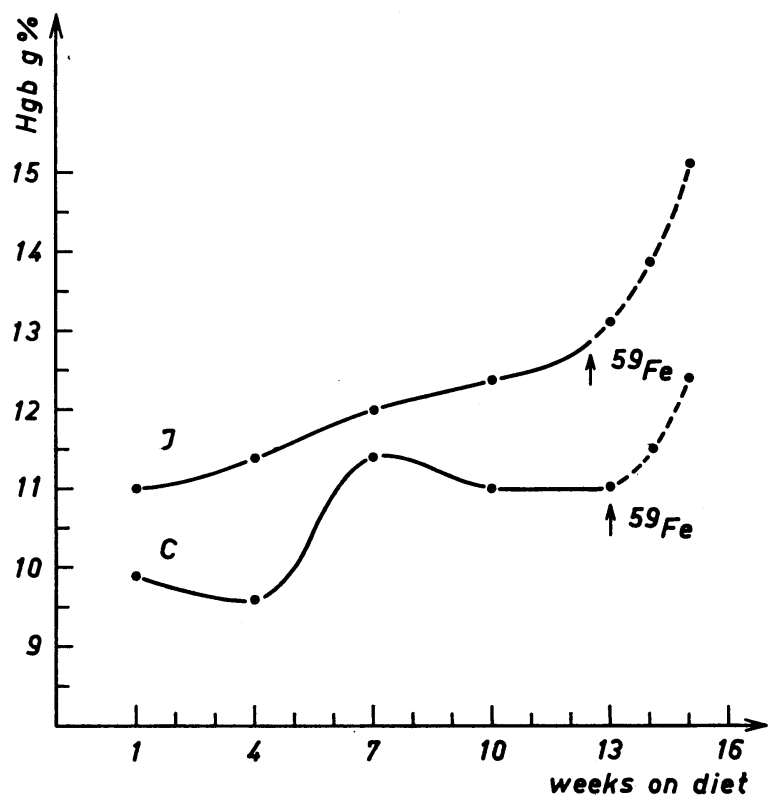

F i g. 6. Haemoglobin values for fattening pigs, used for determination of iron incorporation. I: fed on I-potatoes, C: fed on C-potatoes.

average figures for each group, would therefore be misleading. Comparison should thus be made between those animals in both groups whose initial haemoglobin values were the same. As can be seen from Figures $5 a$ and $b$, the increase in haemoglobin value is appreciable in the I-group. The fact that this difference is further accentuated by a longer period of feeding (larger total potato consumption) is shown by the haemoglobin values of those animals used for iron incorporation and blood volume tests (the dashed lines in Figure 6). These two animals showed even greater differences in haemoglobin concentration than all the other animals, the values being markedly higher for the animal which was fed on I-potatoes. As the blood volume was 
almost the same (see Table III a), the total haemoglobin per se in the animal fed with I-potatoes was thus considerably higher. Apart from this, some increase in the total volume of erythrocytes and some decrease in the plasma volume was found in the I-potato animal. The iron incorporation of these two animals did not exhibit any significant difference. From these values it can be concluded that I-potatoes did not exert any radiomimetic influence on the erythropoietic system. These facts, however, do not explain the mechanism by which the haemoglobin content is increased in the I-group. In order to explain this, two mechanisms must be primarily accounted for: 1 :o prolongation of the lifetime of the erythrocytes combined with normal produktion, or 2:0 increased production of erythrocytes combined with normal lifetime, or a combination of both. The lifetime of erythrocytes has not been determined in this investigation, but in spite of extensive studies by different workers on this subject, no prolongation of the erythrocyte lifetime has been found, except under very extreme conditions, Brock (1) and Lawrence (10). The explanation mentioned in the first case is thus very dubious. With regard to the second case, the normal iron incorporation seems to indicate that no increased erythropoiesis exists in the animals fed with the I-potatoes. Having an unchanged incorporation of iron into the circulating erythrocytes, the body is, however, able to direct more iron into the bone marrow by increasing the iron turnover, i.e. by increasing plasma iron concentration and/or plasma iron disappearance, but these parameters were not investigated.

There is certain evidence, although not significant, indicating that the iron content of the liver is lower in animals fed on I-potatoes. Regarding the numerical differences in Table III b, the higher haemoglobin values observed in the I-group could be presumed to be a result of an increase in utilization (increased mobilisation) of the iron reserve in the liver and/or the other iron deposits in the body. Any increased uptake of iron from the food seems to be improbable.

After castrating and killing the male rats, blood was collected from four animals from each group. No differences in either haemoglobin or haematocrit values could be found. It is possible that the differences in the results obtained for rats and pigs in this respect were due partly to differences in the reaction norms of the species and partly to the fact that the irradiation dose, and 
thus the effect on the potatoes, was of another magnitude and character.

The rather comprehensive examination of the liver function in the fattening pigs, which was performed by determining the transaminases in both blood and liver, did not give any indications of systematic differences. It is a well-known fact that individual variations in the transaminase values of pigs are considerable, Wretlind et al. (19), and therefore any differences between experimental and control animals must be large enough to be detected in small samples.

Only an approximate estimation of the fertility of the pigs could be made. On the basis of the investigation, it can be concluded that one boar and two sows, fed on I-potatoes (total amount for each animal about $500 \mathrm{~kg}$ ) over a period of several months, have demonstrated their fertility.

The present investigation, however, provided detailed information concerning the fertility of the rats. In this case, I-potatoes appear to have a more favourable effect than the $\mathrm{C}$-potatoes. This applied both to the production of offspring by the females, and to the activity of germinal epithelia in the males. The more detailed examination of the fertility of the rats shows that the production of young by the females was high for both groups; an obvious tendency in the fertility activity of the male rats fed on I-potatoes was noted. As compared to the C-group, this difference is not statistically significant, but that could be explained by the relatively large individual variation.

\section{ACKNOWLEDGEMENTS}

The present investigation is part of a research program, financially supported by Jordbrukets Forskningsråd, by Fonden för främjande av forsknings- och försöksverksamheten på jordbrukets område, and by Anslaget till främjande av ograduerade forskares vetenskapliga verksamhet $\mathrm{m}$. $\mathrm{m}$. of the Faculty of Mathematics and Natural Sciences of the Royal University of Stockholm.

Thanks are due to Dr. Stig Larsson, Department of Physiology, The Royal Veterinary College, Stockholm, for performing the transaminase determinations; to Dr. Anna-Lisa Obel, The State Veterinary Medical Institute, Stockholm, for performing the autopsies and the histological tests; to Dr. Dieter Lockner, Institute of Organic Chemistry, The Royal University of Stockholm, for performing the iron incorporation and blood volume determinations; and to Dr. Olle Dahl, Scan, Malmö, for laboratory facilities and for valuable discussions. The tech- 
nical assistance of Miss Signhild ögren, Chem.Eng., Miss Marianne Lundberg, Chem.Eng., and Miss Renate Hartmann, especially by irradiation of the potato tubers, is also gratefully acknowledged.

\section{REFERENCES}

1. Brock, M. A.: Production and life span of erythrocytes during hibernation in the golden hamster. Amer. J. Physiol. 1960, 198, 1181-1186.

2. Dahl, O.: Influence of the basal diet on the quality of pig fat. I. Acta agr. scand. 1958, 8, 106-116.

3. Errington, R. F. \& MacQueen, K. F.: Gamma irradiation of potatoes to inhibit sprouting. Canadian Potato Industry Fifth Annual Conference, University of British Columbia, Vancouver, B.C., August 7, 1961.

4. Herrmann, J.: Die Haltbarmachung von Kartoffeln und Gemüse durch ionisierende Strahlen. Isotopentech. 1962, 2, 33-39.

5. Herrmann, J. \& Raths, J.: Stoffwechselveränderungen in Kartoffeln nach Behandlung mit ionisierenden Strahlen. Nahrung 1958, 2, 1062-1090.

6. Jaarma, M.: Effects of ionizing radiations on inhibition of sprouting and biochemical and physiological changes in potato tubers. Ris $\varnothing$ Report 1960, No. 16, 70-72.

7. Jaarma, M.: Influence of ionizing radiation on potato tubers. Ark. Kemi 1958, 13, 97-105.

8. Jaarma, M.: To be published.

9. Jaarma, M.: To be published.

10. Lawrence, J. H.: Polycythemia. Grune \& Stratton, New York and London, 1955.

11. Lea, C. H.: Rancidity in edible fats. Food Investigation, Special Report 1938, No. 46, $1-230$.

12. Leblond, C. P. \& Clermont, Y.: Spermiogenesis of rat, mouse, hamster, and guinea pigs as revealed by "periodic acid-fuchsin sulfurous acid" technique. Amer. J. Anat. 1952, 90, 167-215.

13. Lockner, D.: Klinische Untersuchungen zur Krebsanämie. Acta haematol. (Basel) 1960, 24, 186-200.

13a. Reichard, H.: Determination of ornithine carbamyl transferase with microdiffusion technique. Scand. J. clin. Lab. Invest. 1957, 9, 311-312.

14. Reitman, S. \& Frankel, S.: A colorimetric method for the determination of serum glutamic oxalacetic and glutamic pyruvic transaminases. Amer. J. Clin. Pathol. 1957, 28, 56-63.

15. Rubin, B. A. \& Metlitskii, L. W.: Die Wirkung ionisierender Strahlen auf den Stoffwechsel in den Speicherorganen von Pflanzen. Sowjetwissenschaft, Naturwissenschaftliche Beiträge 1959, 185-195. 
16. Schwimmer, S., Burr, H. K., Harrington, W. O. \& Weston, W. J.: $\gamma$-Irradiation of potatoes: effects on sugar content, chip color, germination, greening, and susceptibility to mold. Amer. Potato J. 1957, 34, 31-41.

17. Sparrow, A. H. \& Christensen, E.: Improved storage quality of potato tubers after exposure to $\mathrm{Co}^{60}$ gammas. Nucleonics 1954, 12, No. 8, 16-17.

18. Sterling, $K$. \& Gray, S. J.: Determination of the circulating red cell volume in man by radioactive chromium. J. clin. Invest. 1950, 29, 1614-1619.

19. Wretlind, B., Orstadius, K. \& Lindberg, P.: Transaminase and transferase activities in blood plasma and in tissues of normal pigs. Zbl. Vet.-Med. 1959, 6, 963-970.

\section{SUMMARY}

Fattening pigs and pigs for breeding have been fed $\gamma$-irradiated and non-irradiated control potatoes. The irradiation dose was 14-15 kilorad at the rates $175 \mathrm{r} / \mathrm{sec}$. and $625 \mathrm{r} / \mathrm{hr}$. Rats (Wistar) were also fed irradiated and control potatoes, but in this case the tubers were given a dose of about 200 kilorad.

No unfavourable effects have been observed from the feeding with irradiated potatoes. All the facts indicate that the nutritional adequacy of the irradiated and the control tubers is equal. In some cases, the animals have even shown an improvement after feeding on irradiated potatoes which was not apparent after feeding on non-irradiated potatoes; for example there was a more rapid growth, somewhat higher fertility, and increased haemoglobin values. However, current experiments with larger groups of animals will provide more definite evidence in these questions.

\section{ZUSAMMENFASSUNG}

Gesundheit $\gamma$-bestrahlter Kartoffeln.

Mast- und Zuchtschweine wurden mit $\gamma$-bestrahlten und mit nicht bestrahlten Kartoffeln gefüttert. Die angewandte Bestrahlungsdosis betrug 14-15 Kilorad und die Dosisleistungen waren $175 \mathrm{r} / \mathrm{Sek}$ und $625 \mathrm{r} /$ Std. Auch Ratten (Wistar) wurden mit bestrahlten und mit nicht bestrahlten Kartoffeln gefüttert. Die Bestrahlungsdosis betrug in diesem Fall 200 Kilorad.

Es konnten keine unvorteilhaften Effekte bei der Fütterung mit bestrahlten Kartoffeln an den Tieren beobachtet werden. Alle Ergebnisse deuten darauf hin, dass die bestrahlten Kartoffeln als Nahrungsmittel den unbestrahlten vollkommen gleichwertig sind. In gewissen Fällen wurden sogar bei Fütterung mit bestrahlten Kartoffeln günstige Wirkungen, wie z.B. rascheres Wachstum, etwas erhöhte Fertilität und erhöhte Hämoglobinwerte, erzielt. Noch laufende Versuche mit grösseren Tiergruppen werden diese Fragen sicherer beantworten. 


\section{SAMMANFATTNING}

Undersökning av $\gamma$-bestrålad potatis med hänsyn till hälsosamhet.

Gödsvin och avelssvin ha utfodrats med $\gamma$-bestrålad potatis och obestrålad kontrollpotatis. Den använda bestrålningsdosen var 14-15 kilorad och doshastigheterna $175 \mathrm{r} / \mathrm{sek}$ och $625 \mathrm{r} / \mathrm{h}$. Även råttor (Wistar) ha utfodrats med bestrålad potatis och kontrollpotatis, men denna potatis erhöll dosen 200 kilorad.

Inga ofördelaktiga effekter vid utfodring med bestrålad potatis ha observerats. Alla fakta tyda på att den i näringshänseende är fullt likvärdig med kontrollpotatis. I vissa fall har t.o.m. en fördelaktig inverkan på djuren noterats vid utfodring med bestrålad potatis jämfört med obestrålad, t. ex. snabbare tillväxt, något högre fertilitet, ökade hemoglobinvärden. Pågående försök med större djurgrupper komma emellertid att giva ett säkrare besked i dessa frågor.

(Received October 4, 1963). 